\title{
PENGARUH NON PERFORMING LOAN (NPL), LOAN TO DEPOSIT RATIO (LDR) DAN NET INTEREST MARGIN (NIM) TERHADAP RETURN ON ASSETS (ROA) PADA PERUSAHAAN PERBANKAN YANG TERDAFTAR DI BURSA EFEK INDONESIA PADA TAHUN 2015 - 2020.
}

\author{
Kemal Wira Fasha ${ }^{1}$, Abdul Rauf Chaerudin ${ }^{2}$ \\ ${ }^{1,2}$ Fakultas Ekonomi dan Bisnis Universitas Bina Bangsa \\ kemalwf@gmail.com
}

\begin{abstract}
ABSTRAK
Tujuan penelitian ini untuk mengetahui pengaruh Non Perfoming Loan (NPL), Loan to Deposit Ratio (LDR), dan Net Interest Margin (NIM) terhadap Return On Assets (ROA) baik secara parsial maupun secara simultan pada perusahaan perbankan yang terdaftar di Bursa Efek Indonesia. Penelitian ini menggunakan pendekatan kuantitatif dengan data sekunder berupa data Non Perfoming Loan (NPL), Loan to Deposit Ratio (LDR), dan Net Interest Margin (NIM) serta Return On Assets (ROA). Penentuan sampel dalam penelitian ini menggunakan teknik purposive sampling dengan 3 kriteria sehingga didapat 5 perusahaan dari 46 Perusahaan. Teknik analisis yang digunakan adalah teknik analisis regresi data dengan menggunakan bantuan aplikasi SPSS Versi 25. Hasil pengolahan data menunjukan bahwa data berdistribusi normal dan tidak terjadi gejala asumsi klasik dalam penelitian. Kesimpulan yang diperoleh menunjukkan bahwa Non Perfoming Loan (NPL), Loan to Deposit Ratio (LDR) secara parsial berpengaruh negatif dan signifikan terhadap Return On Assets (ROA). Net Interest Margin (NIM) secara parsial berpengaruh positif dan signifikan terhadap Return On Assets (ROA). Serta secara simultan terdapat pengaruh Non Perfoming Loan (NPL), Loan to Deposit Ratio (LDR), dan Net Interest Margin (NIM) terhadap Return On Assets (ROA).
\end{abstract}

Kata kunci : Non Perfoming Loan, Loan to Deposit Ratio, dan Net Interest Margin dan Return On Assets.

\begin{abstract}
The purpose of this study was to determine the effect of Non-Performing Loans (NPL), Loan to Deposit Ratio (LDR), and Net Interest Margin (NIM) on Return On Assets (ROA) either partially or simultaneously in banking companies listed on the Indonesia Stock Exchange. . This study uses a quantitative approach with secondary data in the form of Non-Performing Loan (NPL), Loan to Deposit Ratio (LDR), and Net Interest Margin (NIM) and Return On Assets (ROA). Determination of the sample in this study using purposive sampling technique with 3 criteria in order to obtain 5 companies from 46 companies. The analysis technique used is a data regression analysis technique using the SPSS Version 25 application. The results of data processing show that the data is normally distributed and there are no symptoms of classical assumptions in the study. The conclusion obtained shows that Non-Performing Loans (NPL), Loan to Deposit Ratio (LDR) partially have a negative and significant effect on Return On Assets (ROA). Net Interest Margin (NIM) partially positive and significant effect on Return On Assets (ROA). And simultaneously there is the influence of Non-Performing Loans (NPL), Loan to Deposit Ratio (LDR), and Net Interest Margin (NIM) on Return On Assets (ROA).

Keywords: Non Perfoming Loan, Loan to Deposit Ratio, dan Net Interest Margin dan Return On Assets.
\end{abstract}


PENDAHULUAN

Pentingnya sebuah lembaga perbankan dalam perekonomian, maka diperlukan penilaian kinerja bank sebagai tolak ukur bagi manajemen bank untuk menilai apakah bank telah menjalankan kegiatan usahanya sesuai dengan ketentuan yang berlaku sehingga terhindar dari permasalahan yang telah terjadi pada waktu lalu dan terhindar dari risiko yang dihadapi. Sejak awal tahun 2020, dunia di gemparkan dengan datangnya pandemi virus corona yang berasal dari Wuhan, China. Pandemi Covid-19 menyebabkan keresahan pasalnya kasus virus corona memakan banyak korban jiwa. Wabah virus corona memberikan dampak hebat terhadap perekonomian banyak negara di dunia, termasuk di Indonesia. Yang paling tampak saat ini di beberapa sektor yaitu industri manufaktur, usaha mikro kecil dan menengah (UMKM), industri keuangan, hingga pendapatan individu masyarakat pun ikut terhempas gelombang wabah corona ini.

Kondisi pandemi yang terjadi saat ini mejadi ancaman bagi seluruh sektor bisnis terutama perbankan di indonesia. Untuk dapat bertahan maka perlu ada kebijakan yang dibuat agar meminimalisir dampak pandemi yang dihadapi. Perbankan dituntut untuk meningkatkan kinerjanya terutama kinerja keuangan dan memelihara tingkat kesehatan bank. Kinerja bank dapat dilihat dengan melakukan penilaian melalui sisi kinerja keuangan (financial performance) dan kinerja non keuangan (non financial performance) dalam segi kinerja keuangan terdapat profitabilitas (Ardiansyah, 2020).

Sesuai Undang-Undang No 10 Tahun 1998 Pada tanggal 10 November 1998 tentang perbankan, yang dimaksud dengan bank adalah badan usaha yang menghimpun dana dari masyarakat dalam bentuk simpanan menyalurkan kepada masyarakat dalam bentuk kredit dan atau bentuk-bentuk lainnya dalam rangka meningkatkan taraf hidup rakyat banyak (Kasmir, 2014).

Beberapa rasio yang dapat digunakan untuk melihat kinerja keuangan dan memelihara tingkat kesehatan bank yang baik bagi perusahaan adalah Non Performing Loan (NPL), Loan to Deposit Ratio (LDR), dan Net Interest Margin (NIM). Non Performing Loan (NPL) atau Resiko kredit merupakan suatu risiko akibat kegagalan atau ketidakmampuan nasabah dalam mengembalikan jumlah pinjaman yang diterima beserta bunganya, sesuai jangka waktu yang telah ditentukan (Rahmi, 2014a).

Loan to Deposit Ratio (LDR) atau risiko likuiditas adalah risiko yang mungkin dihadapi oleh bank untuk memenuhi permintaan kredit dan semua penarikan dana tabungan oleh nasabah pada suatu waktu. Loan to Deposit Ratio (LDR) adalah rasio antara seluruh jumlah kredit yang diberikan bank dengan dana yang diterima oleh bank (Dendawijaya. 2009:116). Sebagian 
Prosiding The 1st National Conference on Applied Business, Education, \& Technology (NCABET)"

Unversitas Bina Bangsa 2021

DOI Article : $10.46306 /$ ncabet.v1i1.52

praktisi perbankan menyepakati batas aman LDR suatu bank adalah $80 \%$, namun batas toleransi berkisar antara 85\%-100\% (Rahmi, 2014b).

Net Interest Margin (NIM) atau resiko tingkat bunga merupakan perbandingan antara pendapatan bunga bersih terhadap rata-rata aktiva produktifnya (www.bi.go.id). Net Interest Margin (NIM) ditentukan dari tingkat bunga, semakin besar rasio ini maka pendapatan bunga atas aktiva prorduktif yang dikelola bank akan semakin meningkat, sehingga kemung-kinan bank dalam kondisi berma-salah akan semakin kecil, dengan adanya rasio NIM yang tinggi maka profitabilitas (ROA) bank juga akan meningkat.

Return On Assets (ROA) merupakan perbandingan antara laba bersih dengan total aset perusahaan. Semakin besar ROA suatu bank maka semakin besar pula tingkat keuntungan yang dicapai oleh bank tersebut dan semakin baik pula posisi keuangan bank tersebut dari segi penggunaan asetnya.

Berdasarkan uraian pendahuluan yang diungkapkan sebelumnya dan penelitian yang dilakukan oleh beberapa peneliti terdahulu terkait profitabilitas suatu bank, maka penulis tertarik untuk menguji apakah dengan adanya risiko kredit, risiko liukuiditas dan risiko tingkat bunga berpengaruh terhadap profitabilitas (ROA) suatu bank. Untuk itu penulis tertarik untuk melakukan penelitian dengan judul "Pengaruh Non Performing Loan (NPL), Loan To Deposit Ratio (LDR) Dan Net Interest Margin (NIM) Terhadap Return On Assets (ROA) Pada Perusahaan Perbankan Yang Terdaftar Di Bursa Efek Indonesia Pada Tahun 2015 - 2020.”

\section{Rumusan Masalah}

Berdasarkan yang telah diuraikan dalam latar belakang, maka rumusan masalah yang diambil dalam penelitian ini adalah sebagai berikut:

1. Apakah Non Performing Loan (NPL) berpengaruh terhadap Return On Assets (ROA) pada perusahaan perbankan yang terdaftar di Bursa Efek IndonesiaPeriode tahun 2015$2020 ?$

2. Apakah Loan to Deposit Ratio (LDR) berpengaruh terhadap Return On Assets (ROA) pada perusahaan perbankan yang terdaftar di Bursa Efek IndonesiaPeriode tahun 2015$2020 ?$

3. Apakah Net Interest Margin (NIM) berpengaruh terhadap Return On Assets (ROA) pada perusahaan perbankan yang terdaftar di Bursa Efek IndonesiaPeriode tahun 2015-2020?

4. Apakah Non Performing Loan (NPL), Loan to Deposit Ratio (LDR) dan Net Interest Margin (NIM) berpengaruh secara bersama-sama terhadap Return On Assets (ROA) dan 
Prosiding The 1st National Conference on Applied Business, Education, \& Technology (NCABET)"

Unversitas Bina Bangsa 2021

DOI Article : 10.46306/ncabet.v1i1.52

seberapa besar pengaruhnya pada perusahaan perbankan yang terdaftar di Bursa Efek Indonesia Periode tahun 2015-2020?

\section{Pengertian Return On Assets}

ROA adalah rasio yang dapat memberikan ukuran produktivitas aktiva dalam memberikan pengembalian kedua penanam modal (Paramitha, dkk, 2014). Retutn On Asset (ROA) adalah rasio yang dihitung dengan membagi laba dengan total aset perusahaan. Retutn On Asset (ROA) dinyatakan dalam bentuk presentase (Wira, 2015a).

Return On Asset (ROA) adalah rasio yang digunakan untuk mengukur tingkat profitabilitas suatu perusahaan. ROA digunakan sebagai ukuran kinerja keuangan dan dijadikan sebagai variabel dependen karena ROA digunakan untuk mengukur efektifitas perusahaan didalam menghasilkan keuntungan dengan memanfaatkan aktiva yang dimilikinya (Sinaga, 2018). Hasil pengembalian atas aset merupakan rasio yang menunjukan seberapa besar kontribusi aset dalam menciptakan laba bersih. Dengan kata lain, rasio ini digunakan untuk mengukur seberapa besar jumlah laba bersih yang akakn dihasilkan dari setiap rupiah dana yang tertanam dalam total aset (Hery, 2017)

\section{Pengertian Non Performing Loan (NPL)}

Non Performing Loan (NPL) atau rasio kredit bermasalah adalah perbandingan antara kredit macet dengan total kreditmyang disalurkan oleh bank ke masyarakat (Wira, 2015b). Non Performing Loan (NPL) merupakan rasio yang digunakan untuk mengukur kemampuan bank dalam mengcover resiko kegagalan pengembalian kredit oleh debitur (Yuliana, 2015).

Di sisi lain Rasio NPL digunakan untuk mengukur kemampuan manajemen bank dalam mengelola kredit bermasalah yang diberikan oleh bank. Risiko kredit yang diterima oleh bank merupakan salah satu risiko usaha bank, yang diakibatkan dari ketidakpastian dalam pengembaliannya atau yang diakibatkan dari tidak dilunasinya kembali kredit yang diberikan oleh pihak bank kepada debitur (Hasibuan, 2007). Semakin tinggi rasio ini maka akan semakin buruk kualitas kredit bank yang menyebabkan jumlah kredit bermasalah semakin besar dan menyebabkan kerugian, sebaliknya jika semakin rendah NPL maka laba atau profitabilitas bank tersebut akan semakin meningkat (Dewi, 2015).

\section{Pengertian Loan to Deposit Ratio (LDR)}

Loan to Deposit Ratio (LDR) adalah rasio antara seluruh jumlah kredit yang diberikan bank dengan dana yang diterima oleh bank (Rahmi, 2014a). Loan to Deposit Ratio (LDR) 
Prosiding The 1st National Conference on Applied Business, Education, \& Technology (NCABET)"

Unversitas Bina Bangsa 2021

DOI Article : 10.46306/ncabet.v1i1.52

adalah perbandingan antara kredit yang diberikan dengan dana pihak ketiga (Giro, Tabungan, Deposito, dan kewajiban jangka pendek lainnya) (Almadany, 2014).

Menurut Wildan Farhat Pinasti dalam Kasmir, Loan to Deposit Ratio (LDR) adalah rasio antara seluruh jumlah kredit yang diberikan terhadap dana pihak ketiga. Besarnya jumlah kredit yang disalurkan akan menentukan keuntungan bank. Jika bank tidak mampu menyalurkan kredit sementara terdapat banyak dana yang terhimpun akan menyebabkan kerugian pada bank (Pinasti dan Mustikawati, 2018a).

\section{Pengertian Net Interest Margin (NIM)}

Net Interest Margin (NIM) atau marjin pendapatan bunga bersih adalah perbandingan antara pendapatan bunga bersih dengan nilai aset yang disalurkan sebagai kredit (Wira, 2015c). Net Interest Margin (NIM) merupakan rasio antara pendapatan bunga bersih terhadap rata-rata aktiva produktif. NIM mencerminkan resiko pasar yang timbul akibat berubahnya kondisi pasar dimana hal tersebut dapat merugikan bank (Rahmi, 2014b).

Net Interest Margin (NIM) mencerminkan risiko pasar yang timbul karena adanya pergerakan variabel pasar, di mana hal tersebut dapat merugikan bank. Berdasarkan peraturan Bank Indonesia salah satu proksi dari risiko pasar adalah suku bunga, yang diukur dari selisih antar suku bunga pendanaan (funding) dengan suku bunga pinjaman yang diberikan (lending) atau dalam bentuk absolut adalah selisih antara total biaya bunga pendanaan dengan total biaya bunga pinjaman (Pinasti dan Mustikawati, 2018b). Net Interest Margin (NIM) atau marjin pendapatan bunga bersih adalah perbandingan antara pendapatan bunga bersih bersih dengan nilai aset yang disalurkan sebagai kredit (Wira, 2015d).

\section{Hipotesis Penelitian}

Hipotesis merupakan jawaban sementara terhadap rumusan masalah penelitian, di mana rumusan mmasalah penelitian telah dinyatakan dalam bentuk kalimat pertanyaan (Sugiyono, 2019). Maka hipotesis pada penelitian ini adalah sebagai berikut :

H1: Diduga Non Performing Loan (NPL) berpengaruh terhadap Return On Assets (ROA) pada Perusahaan Perbankan Yang Terdaftar Di Bursa Efek Periode Tahun 2015-2020.

H2: Diduga Loan to Deposit Ratio (LDR) berpengaruh terhadap Return On Assets (ROA) pada Perusahaan Perbankan Yang Terdaftar Di Bursa Efek Periode Tahun 2015-2020.

H3: Diduga Net Interest Margin (NIM) berpengaruh terhadap Return On Assets (ROA) pada Perusahaan Perbankan Yang Terdaftar Di Bursa Efek Periode Tahun 2015-2020. 
H4: Diduga Non Performing Loan (NPL), Loan to Deposit Ratio (LDR), dan Net Interest Margin (NIM) berpengaruh secara bersama-sama dan seberapa besar pengaruhnya terhadap Return On Assets (ROA) pada Perusahaan Perbankan Yang Terdaftar Di Bursa Efek Periode Tahun 2015-2020.

\section{Metode Penelitian}

Menurut (Sugiyono, 2019b) metode penelitian merupakan cara ilmiah untuk mendapatkan data dengan tujuan dan kegunaan tertentu. Penelitian ini menggunakan pendekatan metode kuantitatif dengan menggunakan data sekunder yang meliputi dua variabel. Kedua variabel tersebut adalah variabel dependen yaitu Return On Assets (ROA) serta variabel independen yaitu Non Performing Loan (NPL), Loan to Deposit Ratio (LDR), dan Net Interest Margin (NIM).

Penelitian ini dilaksanakan secara daring di Bursa Efek Indonesia (BEI) Dalam penelitian ini yang menjadi objek penelitian adalah perusahaan perbankan yang menggunakan data sekunder dimana data tersebut diambil secara online dengan mengakses pada situs web resmi yaitu $w w w . i d x . c o . i d$.

\section{Populasi}

Menurut (Sugiyono, 2019c) populasi adalah wilayah generalisasi yang terdiri atas obyek/subyek yang mempunyai kualitas dan karakteristik tertentu yang ditetapkan oleh peneliti untuk dipelajari dan kemudian ditarik kesimpulannya. Populasi dalam penelitian ini adalah perusahaan perbankan yang terdaftar di Bursa Efek Indonesia (BEI) yang berjumlah 46 perusahaan.

\section{Sampel}

Teknik pengambilan sampel yang digunakan dalam penelitian ini yaitu dengan menggunakan teknik purposive sampling. Menurut (Sugiyono, 2019d) purposive sampling adalah teknik penentuan sampel dengan pertimbangan tertentu. Berdasarkan dengan teknik tersebut, maka ditentukan kriteria sampel sebagai berikut:

1. Yang sudah terdaftar di Bursa Efek Indoensia dan perushaan yang berdiri sebelum tahun periode penilitan yaitu tahun 2015 .

2. Perushaaan yang melaporkan data keuangan secara lengkap atau laporan Annual Report hingga tahun 2020.

3. Terdapat laporan keuangan lengkap terkait dengan variabel yang digunakan dalam 
Prosiding The 1st National Conference on Applied Business, Education, \& Technology (NCABET)"

Unversitas Bina Bangsa 2021

DOI Article : 10.46306/ncabet.v1i1.52

penelitian ini yaitu variabel NPL, LDR, NIM, dan ROA.

\section{Teknik Analisis Data}

Statistik deskriptif adalah statistik yang digunakan untuk menganalisis data dengan cara mendeskripsikan atau menggambarkan data yang telah terkumpul sebagaimana adanya tanpa bermaksud membuat kesimpulan yang berlaku untuk umum atau generalisasi (Sugiyono, 2019e).

\section{Tabel 1}

\section{Hasil Pengujian Descriptive Statistics}

Descriptive Statistics

\begin{tabular}{|l|r|r|r|r|r|}
\hline & $\mathrm{N}$ & Minimum & Maximum & Mean & $\begin{array}{c}\text { Std. } \\
\text { Deviation }\end{array}$ \\
\hline NPL & 30 &, 20 & 3,44 & 1,2700 &, 87121 \\
\hline LDR & 30 & 55,35 & 113,50 & 84,354 & 14,96305 \\
& & & & 7 & \\
\hline NIM & 30 & 3,00 & 7,40 & 5,5467 & 1,04872 \\
\hline ROA & 30 &, 13 & 4,00 & 2,3130 & 1,06413 \\
\hline Valid N (listwise) & 30 & & & & \\
\hline
\end{tabular}

Sumber : Data Output IBM SPSS Statistic Ver.25

Berdasarkan hasil statistik deskriptif nilai $\mathrm{N}$ menunjukan jumlah responden ada 30. Dari 30 nilai responden ini varibel Non Perfoming Loan (NPL) menunjukan nilai rata-rata sebesar 1,2700 dengan standard deviasi 0,87121. Nilai minimum Non Perfoming Loan (NPL) adalah 0,20 dan nilai maksimum adalah 3,44. Variabel Loan To Deposit Ratio (LDR) menunjukan nilai rata-rata sebesar 84,3547 dengan standard deviasi 14,96305. Nilai minimum Net Interest Margin (NIM) adalah 3,00 dan nilai maksimum adalah 7,40. Dan nilai variabel menunjukan Return On Assets nilai rata-rata sebesar 2,3130 dengan niai standar deviasinya 1,06413. Nilai minimum Return On Assets adalah 0,13 dan nilai maksimum adalah 4,00.

\section{Pengujian Persyaratan Analisis Data}

\section{a. Uji Normalitas}

Hasil uji normalitas ditunjukan Return On Assets terhadap rasio Non Perfoming Loan (NPL), Loan To Deposit Ratio (LDR), dan Net Interest Margin (NIM ) dengan menggunakan metode Kolmogorov - Smirnov, dapat dilihat pada tabel 2 sebagai berikut: 


\section{Tabel 2}

\section{Hasil Uji Normalitas dengan Kolmogorov - Smirnov}

One-Sample Kolmogorov-Smirnov Test

\begin{tabular}{|c|c|c|}
\hline & & Unstandardized Residual \\
\hline $\mathrm{N}$ & & 35 \\
\hline Normal Parameters ${ }^{\mathrm{a}, \mathrm{b}}$ & Mean & .0000000 \\
\hline & Std. Deviation & 2188.02033860 \\
\hline Most Extreme Differences & Absolute & .113 \\
\hline & Positive & .113 \\
\hline & Negative & -.070 \\
\hline Test Statistic & & .113 \\
\hline Asymp. Sig. (2-tailed) & & $200^{\mathrm{c}, \mathrm{d}}$ \\
\hline
\end{tabular}

Sumber : Data Output IBM SPSS Statistic Ver.25

Hasil uji normalitas Kolmogorov - Smirnov pada table 2 menunjukan bahwa nilai signifikan 0,200 > 0,05 dengan demikian uji normalitas dengan Kolmogorov-Smirnov dapat diambil kesimpulan data berdistribusi normal.

\section{b. Uji Multikolinearitas}

Uji multikolinearitas bertujuan untuk menguji apakah model regresi ditemukan adanya korelasi antar variabel bebas atau independen. Ketentuan yang digunakan adalah jika nilai VIF dari nilai independen $<10$, maka model tidak terdapat multikolinearitas. Namun sebaliknya jika nilai VIF dari variabel independen menunjukan angka > 10, maka model dikatakan telah terjadi multikolinearitas, berikut merupakan tabel yang menunjukan hasil dari uji multikolinearitas:

\section{Tabel 3}

\section{Hasil Pengujian Multikolineritas}

\begin{tabular}{|l|l|r|r|}
\hline \multicolumn{4}{|c|}{ Coefficients $^{\text {a }}$} \\
\hline \multirow{4}{*}{ Model } & Collinearity Statistics \\
\cline { 3 - 4 } & & Tolerance & VIF \\
\hline 1 & (Constant) & & \\
\cline { 2 - 4 } & NPL &, 754 & 1,327 \\
\cline { 2 - 4 } & LDR &, 776 & 1,288 \\
\cline { 2 - 4 } & NIM &, 640 & 1,561 \\
\hline \multicolumn{3}{|l|}{ a. Dependent Variable: ROA } \\
\hline
\end{tabular}

\section{Sumber : Data Output IBM SPSS Statistic Ver.25}

Berdasarkan tabel 3 diatas menunjukan nilai tolerance variabel Non Perfoming Loan (NPL) sebesar 0,754>0,10. Loan To Deposit Ratio (LDR) sebesar 0,776>0,10. dan Net Interest Margin (NIM ) sebesar 0,640>0,10. Hasil perhitungan nilai Variance Inflation Factor (VIF) juga menunjukan variabel variabel Non Perfoming Loan (NPL) sebesar 1,327<10. Loan To Deposit Ratio (LDR) sebesar 1,288< 10. dan Net Interest Margin (NIM ) sebesar 1,561<10. 
Prosiding The 1st National Conference on Applied Business, Education, \& Technology (NCABET)"

Unversitas Bina Bangsa 2021

DOI Article : 10.46306/ncabet.v1i1.52

Jadi dapat disimpulkan bahwa tidak ada multikolinearitas antara variabel independen dalam model regresi.

\section{c. Uji Heteroskedastisitas}

Uji heterokedastitas bertujuan untuk menguji apakah dalam model regresi terjadi ketidaksamaan variance dari residual satu pengamatan ke pengamatan yang lain. Apabila grafik menampilkan sebaran titik titik data membentuk suatu pola (Melebar, menyempit dan bergelombang) heteroskedatisitas dan sebalik nya apabila titik-titik data menyebar secara acak dan tidak membentuk pola yang jelas. Berikut ini adalah hasil dari uji heterokedastitas:

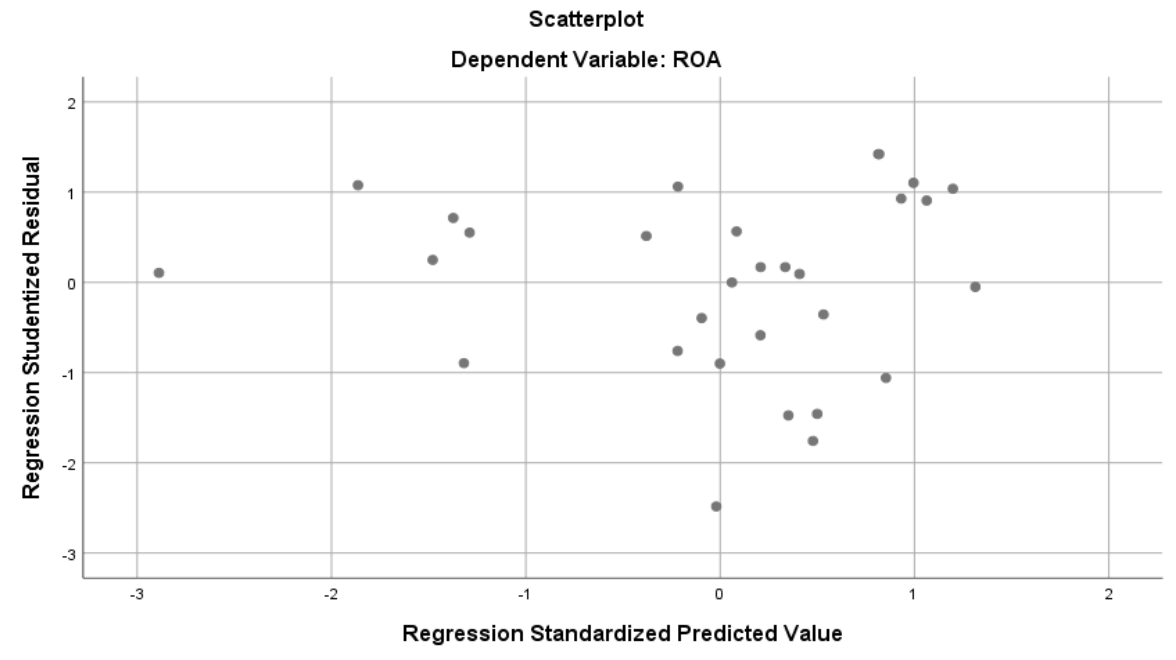

Sumber : Data Output IBM SPSS Statistic Ver.25

\section{Gambar 1 Hasil Pengujian Heteroskedastitas}

Hasil uji heteroskedasitas dapat dilihat pada gambar 1 yang menunjukan bahwa sebaran titk-titik data berpencar secara acak disekitar angka 0 dan sumbu Y dan tidak membentuk suatu pola atau tren garis tertentu sehingga dapat disimpulkan bahwa data tidak terjadi gejala heteroskedastisitas dan analisis regresi dapat dilakukan.

\section{d. Uji Autokorelasi}

Uji Autokorelasi dimaksudkan untuk mengetahui apakah terjadi korelasi diantara data pengamatan atau tidak. Metode yang digunakan dalam pengujian ini adalah dengan Durbin Watson (DW). Berikut ini adalah hasil uji Autokorelasi:

\section{Tabel 4}

\section{Hasil Uji Autokorelasi}

\begin{tabular}{|l|l|l|l|l|l|}
\hline \multicolumn{7}{|c|}{ Model Summary $^{\mathbf{b}}$} \\
\hline Model & R & R Square & $\begin{array}{c}\text { Adjusted R } \\
\text { Square }\end{array}$ & $\begin{array}{c}\text { Std. Error of } \\
\text { the Estimate }\end{array}$ & $\begin{array}{c}\text { Durbin- } \\
\text { Watson }\end{array}$ \\
\hline
\end{tabular}




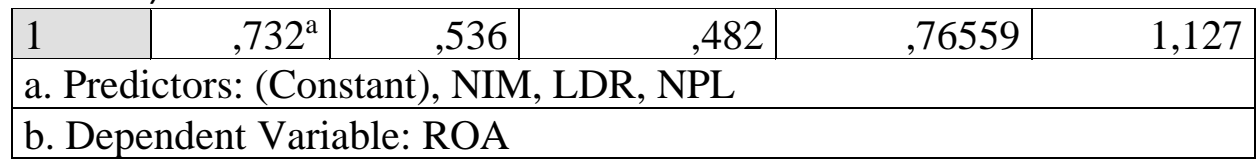

Dari perhitungan di atas dengan menggunakan SPSS versi 25, nilai Durbin-Watson (DW) yang didapat adalah sebesar 1,127 yang berarti nilai DW tersebut terletak antar -2 sampai dengan +2 , sehingga kesimpulan yang didapat untuk model ini adalah tidak ada Autokorelasi.

\section{Uji Regresi Linier Berganda}

Analisis regresi linier berganda ini digunakan untuk mengetahui besarnya pengaruh dari variabel independen terhadap variabel dependen. Analisis regresi merupakan suatu tehnik untuk membangun persamaan dan menggunakan persamaan tersebut untuk membuat perkiraan.

\section{Tabel 5}

\section{Hasil Uji Regresi Linier Berganda}

\begin{tabular}{|c|c|c|c|c|c|c|}
\hline \multicolumn{7}{|c|}{ Coefficients $^{\mathbf{a}}$} \\
\hline & & \multicolumn{2}{|c|}{$\begin{array}{c}\text { Unstandardized } \\
\text { Coefficients } \\
\end{array}$} & \multirow{2}{*}{$\begin{array}{c}\text { Standardized } \\
\text { Coefficients } \\
\text { Beta }\end{array}$} & \multirow[b]{2}{*}{$\mathrm{T}$} & \multirow[b]{2}{*}{ Sig. } \\
\hline \multicolumn{2}{|c|}{ Model } & B & Std. Error & & & \\
\hline \multirow[t]{4}{*}{1} & (Constant) & 5,592 & 1,713 & & 3,265 & ,003 \\
\hline & NPL &,- 548 & , 188 &,- 449 & $-2,915$ & ,007 \\
\hline & LDR &,- 037 & , 011 &,- 526 & $-3,471$ & ,002 \\
\hline & NIM & , 104 & , 169 & ,102 & ,611 & ,546 \\
\hline
\end{tabular}

a. Dependent Variable: ROA

Sumber : Data Output IBM SPSS Statistic Ver.25

Dari hasil tabel 5 diatas dapat terlihat bahwa perhitungan analisis regresi linier berganda yang dapat dirumuskan ke dalam persamaan regresi sebagai berikut ini:

$\mathrm{Y}=5.592+(-0.548 \mathrm{X} 1)+(-.037 \mathrm{X} 2)+0.104 \mathrm{X} 3$

$$
\mathrm{Y}=\mathrm{a}+\mathrm{b}_{1} \mathrm{X}_{1}+\mathrm{b}_{2} \mathrm{X}_{2+} \mathrm{X}_{3} \mathrm{~b}_{3}
$$


Prosiding The 1st National Conference on Applied Business, Education, \& Technology (NCABET)"

Unversitas Bina Bangsa 2021

DOI Article : 10.46306/ncabet.v1i1.52

Keterangan :

$\mathrm{Y}=$ Variabel dependen (Harga Saham)

$\mathrm{a}=$ Konstanta

$\mathrm{b}_{1}=$ koefisien regresi Return On Equity

$\mathrm{b}_{2}=$ koefisien regresi Current Ratio

$\mathrm{X}_{1}=$ Return On Equity

$\mathrm{X}_{2}=$ Current Ratio

\section{Uji Koefisien Korelasi dan Determinasi}

\section{a. Koefisien Korelasi}

Koefisien korelasi berganda adalah angka yang digunakan untuk mengetahui tingkat pengaruh antar variabel independen secara bersama-sama dengan variabel dependen, yaitu antara $\mathrm{X}_{1}, \mathrm{X}_{2}$ dan $\mathrm{X}_{3}$ terhadap Y. Hasil Uji Koefisien Korelasi berganda sebagai berikut:

\section{Tabel 6}

Hasil Pengujian Koefisien Korelasi Variabel NPL, LDR, dan NIM Terhadap ROA

\begin{tabular}{|l|c|r|c|r|r|}
\hline \multicolumn{7}{|c|}{ Model Summary $^{\mathbf{b}}$} \\
\hline Model & $\mathrm{R}$ & R Square & $\begin{array}{c}\text { Adjusted R } \\
\text { Square }\end{array}$ & $\begin{array}{l}\text { Std. Error of } \\
\text { the Estimate }\end{array}$ & $\begin{array}{c}\text { Durbin- } \\
\text { Watson }\end{array}$ \\
\hline 1 &, $732^{\mathrm{a}}$ &, 536 &, 482 &, 76559 & 1,127 \\
\hline a. Predictors: (Constant), NIM, LDR, NPL \\
\hline
\end{tabular}

Berdasarkan hasil tabel 6. diketahui bahwa besarnya hubungan antara Non Performing Loan, Loan To Deposit Ratio, Net Interest Margin terhadap Return On Assets yang dihitung dengan koefisien korelasi berganda adalah 0,732 berada pada rentang "0.600-0.799" yang berarti terjadi hubungan yang kuat antara Non Performing Loan, Loan To Deposit Ratio, Net Interest Margin terhadap Return On Assets

\section{Koefisien Determinasi}

Berikut hasil uji koefisien determinasi secara bersama-sama (Simultan) antara variabel ROE dan CR terhadap Harga Saham:

\section{Tabel 7}

\section{Hasil Pengujian Koefisien Determinasi Variabel NPL, LDR, dan NIM Terhadap ROA}

\begin{tabular}{|l|c|r|r|r|r|}
\hline \multicolumn{7}{|c|}{ Model Summary $^{\mathbf{b}}$} \\
\hline Model & R & R Square & $\begin{array}{c}\text { Adjusted R } \\
\text { Square }\end{array}$ & $\begin{array}{c}\text { Std. Error of } \\
\text { the Estimate }\end{array}$ & $\begin{array}{c}\text { Durbin- } \\
\text { Watson }\end{array}$ \\
\hline 1 &, $732^{\mathrm{a}}$ &, 536 &, 482 &, 76559 & 1,127 \\
\hline
\end{tabular}


Berdasarkan tabel 7 diperoleh nilai koefisien determinasi parsial variabel NPL, LDR, NIM terhadap ROA sebesar 0,536 atau sama dengan 53,6\%. Hal ini menunjukan bahwa besarnya pengaruh NPL, LDR, NIM terhadap ROA sebesar 53,6\%, sedangkan sisanya 56,4\% dipengaruhi oleh variabel lain yang tidak diteliti oleh penelitian ini.

\section{Pengujian Hipotesis}

\section{Uji t (Uji Parsial)}

Uji-t adalah uji yang dipakai untuk mengetahui ada tidaknya pengaruh masing-masing variabel bebas secara parsial terhadap harga saham pada perusahaan perbankan yang terdaftar di Bursa Efek Indonesia Periode 2015-2020. Berikut adalah hasil output SPSS mengenai untuk uji secara parsial:

\section{Tabel 8}

\section{Hasil Pengujian Uji t}

\begin{tabular}{|c|c|c|c|c|c|c|}
\hline \multicolumn{7}{|c|}{ Coefficients $^{\mathrm{a}}$} \\
\hline \multirow{2}{*}{\multicolumn{2}{|c|}{ Model }} & \multicolumn{2}{|c|}{$\begin{array}{l}\text { Unstandardized } \\
\text { Coefficients }\end{array}$} & \multirow{2}{*}{$\begin{array}{c}\begin{array}{c}\text { Standardized } \\
\text { Coefficients }\end{array} \\
\text { Beta } \\
\end{array}$} & \multirow[b]{2}{*}{$\mathrm{T}$} & \multirow[b]{2}{*}{ Sig. } \\
\hline & & B & Std. Error & & & \\
\hline \multirow[t]{4}{*}{1} & (Constant) & 5,592 & 1,713 & & 3,265 &, 003 \\
\hline & NPL &,- 548 & , 188 &,- 449 & $-2,915$ & ,007 \\
\hline & LDR &,- 037 & ,011 &,- 526 & $-3,471$ &, 002 \\
\hline & NIM &, 104 & , 169 &, 102 & ,611 &, 546 \\
\hline
\end{tabular}

a. Dependent Variable: ROA

\section{Sumber : Data Output IBM SPSS Statistic Ver.25}

\section{1) Pengaruh Non Perfoming Loan (NPL) Terhadap Return On Assets}

Karena nilai thitung diperoleh bernilai negatif maka asumsi dasar pengambilan keputusan jadi terbalik sehingga $-\mathrm{t}_{\text {hitung }}<-\mathrm{t}_{\text {tabel }}(-2,915<-2.048)$ dan nilai signifikansi $(0.007<0.05)$ maka $\mathrm{H}_{0}$ ditolak dan $\mathrm{H}_{1}$ diterima. Berdasarkan uji signifikansi diperoleh bahwa ada pengaruh secara negatif antara Non Perfoming Loan (NPL) Terhadap Return On Assets pada perusahaan perbankan yang terdaftar di Bursa Efek Indonesia Periode 2015-2020.

\section{2) Pengaruh Loan To Deposit Ratio (LDR) Terhadap Return On Assets}

Karena nilai $t_{\text {hitung }}$ diperoleh bernilai negatif maka asumsi dasar pengambilan keputusan jadi terbalik sehingga $-\mathrm{t}_{\text {hitung }}<-\mathrm{t}_{\text {tabel }}(-3,471<-2.048)$ dan nilai signifikansi $(0.002<0.05)$ maka $\mathrm{H}_{0}$ ditolak dan $\mathrm{H}_{2}$ diterima. Berdasarkan uji signifikansi diperoleh bahwa ada pengaruh secara negatif antara Loan To Deposit Ratio (LDR) Terhadap Return On Assets pada perusahaan perbankan yang terdaftar di Bursa Efek Indonesia Periode 2015-2020. 
Prosiding The 1st National Conference on Applied Business, Education, \& Technology (NCABET)"

Unversitas Bina Bangsa 2021

DOI Article : 10.46306/ncabet.v1i1.52

\section{3) Pengaruh Net Interest Margin Terhadap Return On Assets}

Karena nilai $t_{\text {hitung }}<\mathrm{t}_{\text {tabel }}(-0,611<2.048)$ dan nilai signifikansi $(0.546<0.05)$ maka $\mathrm{H}_{0}$ ditolak dan $\mathrm{H}_{3}$ diterima. Berdasarkan uji signifikansi diperoleh bahwa ada pengaruh secara positif antara Net Interest Margin Terhadap Return On Assets pada perusahaan perbankan yang terdaftar di Bursa Efek Indonesia Periode 2015-2020.

\section{Uji F (Uji Simultan)}

Pengujian Uji F ini dilakukan untuk mengetahui apakah variabel-variabel indpenden secara bersama-sama (Simultan) dapat berpengaruh terhadap variabel dependen. Jika Nilai $F_{\text {hitung }}>$ $\mathrm{F}_{\text {tabel }}$ atau sig $\mathrm{F}<0,05$ maka $\mathrm{H}_{0}$ ditolak dan $\mathrm{H}_{4}$ diterima yang berarti Loan to Deposit Ratio (LDR) dan Net Interest Margin (NIM) berpengaruh secara bersama-sama terhadap Return On Assets (ROA) pada perusahaan perbankan yang terdaftar di Bursa Efek Indonesia Periode tahun 2015-2020.

\section{Tabel 9}

\section{Hasil Pengujian Uji F}

\begin{tabular}{|c|c|c|c|c|c|c|}
\hline \multicolumn{7}{|c|}{ ANOVA $^{a}$} \\
\hline \multicolumn{2}{|c|}{ Model } & $\begin{array}{l}\text { Sum of } \\
\text { Squares }\end{array}$ & Df & Mean Square & $\mathrm{F}$ & Sig. \\
\hline \multirow[t]{3}{*}{1} & Regression & 17,599 & 3 & 5,866 & 10,009 &, $000^{\mathrm{b}}$ \\
\hline & Residual & 15,239 & 26 &, 586 & & \\
\hline & Total & 32,839 & 29 & & & \\
\hline
\end{tabular}

Berdasarkan nilai $F_{\text {hitung }}>F_{\text {tabel }}(10.009>2.98)$ dan nilai signifikan $\alpha\left(0,000<0,05\right.$ maka $\mathrm{H}_{0}$ ditolak dan $\mathrm{H}_{4}$ diterima. Berdasarkan hal tersebut maka dapat disimpulkan bahwa terdapat pengaruh antara variabel Loan to Deposit Ratio (LDR) dan Net Interest Margin (NIM) berpengaruh secara bersama-sama terhadap Return On Assets (ROA) pada perusahaan perbankan yang terdaftar di Bursa Efek Indonesia Periode tahun 2015-2020

\section{SIMPULAN}

Berdasarkan hasil penelitian dan pembahasan pada penelitian ini maka, dapat disimpulkan sebagai berikut:

1. Berdasarkan hasil perhitungan output olah data spss versi 25 dengan uji t diperoleh nilai thitung diperoleh bernilai negatif maka asumsi dasar pengambilan keputusan jadi terbalik sehingga $-\mathrm{t}_{\text {hitung }}<-\mathrm{t}_{\text {tabel }}(-2,915<-2.048)$ dan nilai signifikansi $(0.007<0.05)$ maka $\mathrm{H}_{0}$ ditolak dan $\mathrm{H}_{1}$ diterima. Berdasarkan uji signifikansi diperoleh bahwa ada pengaruh secara 
negatif antara Non Perfoming Loan (NPL) Terhadap Return On Assets pada perusahaan perbankan yang terdaftar di Bursa Efek Indonesia Periode 2015-2020.

2. Berdasarkan hasil perhitungan output olah data spss versi 25 dengan uji $t$ diperoleh $t_{\text {hitung }}$ diperoleh bernilai negatif maka asumsi dasar pengambilan keputusan jadi terbalik sehingga $-\mathrm{t}_{\text {hitung }}<-\mathrm{t}_{\text {tabel }}(-3,471<-2.048)$ dan nilai signifikansi $(0.002<0.05)$ maka $\mathrm{H}_{0}$ ditolak dan $\mathrm{H}_{2}$ diterima. Berdasarkan uji signifikansi diperoleh bahwa ada pengaruh secara negatif antara Loan To Deposit Ratio (LDR) Terhadap Return On Assets pada perusahaan perbankan yang terdaftar di Bursa Efek Indonesia Periode 2015-2020.

3. Berdasarkan hasil perhitungan output olah data spss versi 25 dengan uji t diperoleh $t_{\text {hitung }}$ $<\mathrm{t}_{\text {tabel }}(-0,611<2.048)$ dan nilai signifikansi $(0.546<0.05)$ maka $\mathrm{H}_{0}$ ditolak dan $\mathrm{H}_{3}$ diterima. Berdasarkan uji signifikansi diperoleh bahwa ada pengaruh secara positif antara Net Interest Margin Terhadap Return On Assets pada perusahaan perbankan yang terdaftar di Bursa Efek Indonesia Periode 2015-2020.

4. Berdasarkan nilai $F_{\text {hitung }}>F_{\text {tabel }}(10.009>2.98)$ dan nilai signifikan $\alpha(0,000<0,05$ maka $\mathrm{H}_{0}$ ditolak dan $\mathrm{H}_{4}$ diterima. Berdasarkan hal tersebut maka dapat disimpulkan bahwa terdapat pengaruh antara variabel Loan to Deposit Ratio (LDR) dan Net Interest Margin (NIM) berpengaruh secara bersama-sama terhadap Return On Assets (ROA) pada perusahaan perbankan yang terdaftar di Bursa Efek Indonesia Periode tahun 2015-2021

Berdasarkan kesimpulan diatas, maka saran yang dapat diberikan antara lain:

1. Bagi peneliti selanjutnya diharapkan dapat menambahkan variabel-variabel lain yang dapat mempengaruhi Return On Assets (ROA) sebagai variabel independennya.

2. Bagi perusahaan perbankan dalam meningkatkan kinerja perusahaan perbankan sebaiknya memperhatikan tingkat likuiditas, pendapatan bunga bersih, dan laba untukmengukur efektifitas perusahaan dalam menghasilkan keuntungan dan mampu menekan jumlah kredit bermasalah agar kualitas kinerja bank tersebut semakin meningkat

3. Bagi pihak perusahaan harus lebih meningkatkan nilai laba/keuntungan perusahaan untuk mengoptimalkan penggunaan dana dan meminimalisir biaya operasi agar tercipta efesiensi dan efektifitas penggunaan dana.

4. Untuk penelitian ini disarankan agar jumlah periode pengambilan sampel di perpanjang dan di tambah sehingga sampel bertambah banyak dan menghasilkan hasil penelitian yang lebih akurat.

\section{DAFTAR PUSTAKA}


Prosiding The 1st National Conference on Applied Business, Education, \& Technology (NCABET)"

Unversitas Bina Bangsa 2021

DOI Article : 10.46306/ncabet.v1i1.52

Almadany, Khairunnisa. 2014. Pengaruh Loan to Deposit Ratio, Biaya Operasional Pendapatan

Operasional dan Net Interest Margin Terhadap Profitabilitas Perusahaan Perbankan yang Terdaftar di Bursa Efek Indonesia. Jurnal Riset Akuntansi dan Bisnis 12.2

Ardiansyah, Riko. 2020. Pengaruh RisikoLikuiditas , Cadangan Kas dan Risiko NPL terhadap Profitabilitas Perbankan selama Covid-19. Jurnal Kompetitif Bisnis Edisi Covid 19. Vol.1 No.1

Dewi, Aminar Sutra. 2017. Pengaruh Car, Bopo, Npl, Nim, dan Ldr terhadap Roa pada perusahaan di sektor perbankan yang terdaftar di bei periode 2012-2016. Jurnal Pundi. Vol 01 No 03.

Dewi, Luh Eprima, et al. 2015. Analisis Pengaruh NIM, BOPO, LDR, dan NPL Terhadap Profitabilitas (Studi Kasus Pada Bank Umum Swasta Nasional Yang Terdaftar Pada Bursa Efek Indonesia Periode 2009-2013). JIMAT (Jurnal Ilmiah Mahasiswa Akuntansi) Undiksha 3.1

Fiscal, Yunus, and Lili Lusiana, 2014. Pengaruh Capital Adequacy Ratio (CAR), Loan to Deposit Ratio (LDR), Biaya Operasional dan Pendapatan Operasional (BOPO) Terhadap Profitabilitas BPR. Jurnal Akuntansi Dan Keuangan Vol. 5 No. 2

Handayani, Wuri. 2017. Pengaruh Risiko Kredit, Risiko Likuiditas dan Risiko Tingkat Bunga Terhadap ROA. Jurnal Sikap 1.2

Harun, Usman. 2016, Pengaruh Ratio-Ratio Keuangan CAR, LDRR, NIM, BOPO, dan NPL Terhadap Roa. Jurnal Riset Bisnis Manajemen. Vol 4 No 4

Kurniasih, Erma. 2016. Pengaruh Capital Adequacy Ratio, Non Performing Loan, Loan To Deposit Ratio, Efisiensi Operasi, Not Interest Margin Terhadap Return On Aset (Studi Empiris pada Perusahaan Perbankan yang Listing di BEI tahun 2009-2014). Journal Of Accounting 2.2

Paramitha, Ni Nyoman Karisma Dewi, I. Wayan Suwendra, and Fridayana Yudiaatmaja. 2014.

Pengaruh Risiko Kredit Dan Likuiditas Terhadap Profitabilitas Pada Perusahaan Perbankan Yang Go Public Periode 2010-2012. Jurnal Manajemen Indonesia 2.1

Pinasti, Wildan Farhat, and RR Indah Mustikawati. 2018. Pengaruh CAR, BOPO, NPL, NIM Dan LDR Terhadap Profitabilitas Bank Umum Periode 2011-2015. Nominal: Barometer Riset Akuntansi dan Manajemen 7.1

Pratiwi, Luh Putu Sukma Wahyuni dan Ni Luh Putu Wiagustini, 2015. Pengaruh Car, Bopo, Npl, Dan Ldr Terhadap profitabilitas. e-jurnal manajemen unud. Vol 5 No 4 Puspitasari, Denik, And Yahya Yahya. 2020. Pengaruh Current Ratio, Net Profit Margin Dan Earning Per Share Terhadap Harga Saham. Jurnal Ilmu Dan Riset Manajemen (Jirm) 
Prosiding The 1st National Conference on Applied Business, Education, \& Technology (NCABET)"

Unversitas Bina Bangsa 2021

DOI Article : 10.46306/ncabet.v1i1.52

Puspitasari, Elisa. 2014. Analisis Faktor-Faktor Yang Mempengaruhi Net Interest Margin pada Bank-Bank Umum Di Indonesia. Jurnal Ilmu Manajemen (JIM) 2.4

Rahmi, Ceria Lisa. 2014. Pengaruh Risiko Kredit, Risiko Likuiditas Dan Risiko Tingkat Bunga Terhadap Profitabilitas (Studi Empiris pada Perusahaan Perbankan Terdaftar di Bursa Efek Indonesia). Jurnal Akuntansi 2.3

Ramadhani , Aulia Nazala dan Astiwi Indrianni. 2016. Analisis Pengaruh Size, Capital, Capital Adequacy Ratio (Car), Return On Asset (Roa), Non Performing Loan (Npl), dan Inflasi Terhadap Loan To Deposit Ratio (Ldr). Diponegoro Journal Of Management. Vol 5 No 2.

Ritonga, Zuraini. 2014. Analisis Rasio Kecukupsn Modal Perbankan dan Pengaruhnya Terhadap Kinerja Keuangan Perbankan Yang Terdapat Di Bursa Efek Indonesia 2014. Jurnal Ecobisma. Vol 1 No. 1

Sinaga, Metaria Septiana. 2018, "Pengaruh Risiko Kredit, Risiko Likuiditas, Risiko Tingkat Bunga, Tingkat Kecukupan Modal, dan Efisiensi Operasional Terhadap Profitabilitas pada Bank Umum yang Terdaftar di Bursa Efek Indonesia.

Wulan, Nurul dan Budi Herman. Analisis Biaya Dana, Presntase Aktiva Produktif, Dan pendapatan sebagai faktor pembeda antara bank fokus dan bank terbatas menurut kerangka arsitektur perbankan indonesia. ug jurnal. Vol 1 no 2

Yuliana, Amalia. 2015. Pengaruh LDR, CAR,ROA dan NPL terhadap penyaluran kredit pada bank umum di indonesia periode 2008-2013. Jurnal Dinamika Manajemen. Vol. 2, No.3 